Investigations

\title{
Morphology, Anatomy, Chlorogenic Acid Content and Antioxidant Capacity of Xanthium strumarium L. and Xanthium spinosum L.
}

\author{
${ }^{1}$ Dinara Abdikhaliyevna Aldibekova, ${ }^{2}$ Murat Kizaibek, ${ }^{3}$ Mahaya Aisijiang, \\ ${ }^{1}$ Gulzhamal Dyuskaliyeva, ${ }^{2}$ Angsar Taldau and ${ }^{2}$ Mainur Erkinbek \\ ${ }^{1}$ Kazakh State Women's Teacher Training University, Almaty 050000, Kazakhstan \\ ${ }^{2}$ Traditional Kazakh Medicine Research Institute of Ili Kazakh Autonomous Prefecture, Yining 835000, China \\ ${ }^{3}$ College of Chemistry and Environmental Science, Yili Normal University, Yining, 835000, China
}

\section{Article history}

Received: 21-02-2018

Revised: 27-02-2018

Accepted: 22-05-2018

Corresponding Author: Dinara Abdikhaliyevna Aldibekova

Teacher Training University, Almaty 050000, Kazakhstan

E-mail: aldibekova.dinar@gmail.com
Kazakh State Women's

\begin{abstract}
In this study, the morphological, anatomical features, chlorogenic acid content and antioxidant activities of two species from the genus Xanthium, namely Xanthium spinosum L. growing in the slopes of Mount Daubaba in the western part of the Talas Alatau of Tyulkibas region of the South Kazakhstan region and Xanthium strumarium L. growing in the slopes of the Alma-Arasan gorge of the Trans-Ili Alatau, Almaty region, were investigated. Xanthium strumarium L. is a one-year-old widespread plant. Height is $20-100 \mathrm{~cm}$, leaves are straight, pubescent, thinly faceted. On the surface of the stem there are greyish-green or browngreen spots. Xanthium spinosum L. - height is $25-100 \mathrm{~cm}$. Difference of stems from species Xanthium strumarium L. is thickly branched, creeping, low-directed small solid hairs. The main and lateral roots of the plant are well developed. The anatomical structure of the transverse cut of the root of species of the genus Xanthium L. is rounded. The epidermis is completely preserved. In the anatomical structure of the stem the epidermis of the stem is well developed in species Xanthium L. The central cylinder is closed collateral, the single conducting beams are arranged ring-shaped. The leaf plate of the species Xanthium L. consists of loose mesophilic and stem tissues. Conductive beams are well formed in the central system. Besides, a simple, precise, repeatable and accurate HPLC method for determination of chlorogenic acid in samples from the genus Xanthium was developed and validated. It is also observed that the extracts obtained from the leaves or stems of these plants have significant antioxidant activity, which correlated well with chlorogenic acid content of these samples, indicating that chlorogenic acid could be important contributor of antioxidant capacities of species of the genus Xanthium L.
\end{abstract}

Keywords: Anatomical Structure, Xanthium strumarium L., Xanthium spinosum L., Morphological Features, Epidermis, Chlorogenic Acid, Antioxidant Activity

\section{Introduction}

At the moment, for the treatment of various diseases,

Flora of Kazakhstan is rich in useful plants and especially important medicinal plants. Preparations made from them are widely used. As a result, phytotherapy is developing in Kazakhstan massively. Recently, some medicinal plants are close to extinction or completely disappeared as a result of wasteful use. Therefore, it is necessary not only to use medicinal plants; they must be protected (Rakhimov et al., 1999). special attention is drawn to medicinal plants. Kazakhstan, like other countries, is interested in the production of phytopreparations for medicine. Investigation of morphological, anatomical features and chemical composition is considered relevant to learn the biological feature of the plant. Also, the definition of anatomical diagnostic features of medicinal plants in the development of vegetative organs raises the quality of raw materials in the selection for the use in 
pharmacology (Georgievsky et al., 1990). In the study of medicinal plants, the traditional comparative morphological and anatomical methods are widely used. In this aspect, particular attention will be paid to plant species having a sufficient stock of raw materials in the native flora. One of the genera of such plants is Xanthium L. The distribution area of two species from this genus grown in Kazakhstan is shown on Fig. 1. Xanthium strumarium L. (common cocklebur) is a oneyear plant belonging to the family of composites (Asteraceae). It grows on the banks of rivers and irrigation ditches, at the edges of the road, in kitchen gardens, on rocky sediments and in the steppes. Xanthium spinosum L. (cocklebur spiny) grows in mountain, desert and sandy lands (Flora of Kazakhstan, 1961). Xanthium strumarium L. (Family: Compositae), a medicinal plant commonly found as a weed, is widely distributed in North America, Brazil, China, Malaysia and hotter parts of India (Kamboj et al., 2014). Xanthium strumarium L. is an herb that possesses antiinflammatory, analgesic (Han et al., 2007; Yin et al., 2005), antibacterial, anticancer effects (Ramírez-Erosa et al., 2007; Kim et al., 2003) and antifungal (Dong et al., 2002) effects. In India it is used in the treatment of scabies and for the purification of blood. It eliminates worms in the intestines, lowers the temperature. It is diuretic and it invigorates, digests food, improves skin color, helps with skin whiteness and is used as an antidote against insects. Leaves are used for herpes, malaria, headaches and oncologiculcers (Bhogaonkar and Ahmad,
2012). In Yemen and in Russia in folk medicine the plant Xanthium strumarium L. is used as a medicine soothing illness, hemolytic, reducing temperature, also for skin diseases, as antimicrobial, for ulcers and as an antifungal. According to research of Romanian scientists, a $2 \%$ tincture of the cocklebur germ has a diuretic effect (Salekh, 2010). The results of investigation of alcoholic and water extracts of Xanthium strumarium L. carried out by Indian researchers demonstrated that alcoholic extracts (EEXS) $250 \mathrm{mg} / \mathrm{kg}$ and $500 \mathrm{mg} / \mathrm{kg}$ ) of Xanthium strumarium L. possessed significant anti-diabetic activity (169.67 \pm 5.65$), \quad(158.2 \pm 4.6)$ in comparison to water extract (AEXS) in a dose dependent manner and presence of phenols, flavonoids and tannins were found to be responsible for the activity (Suresh et al., 2014). During in vitro assays the phytochemical investigation of the natural products from Xanthium strumarium L. was carried out by Korean researchers. The fourteen compounds including seven caffeoylquinic acid (CQA) derivatives were isolated and screened for inhibition of $\alpha$-glucosidase, protein tyrosine phosphatase $1 \beta$ (PTP1 $\beta$ ), advanced glycation end products (AGEs) and ABTS+ radical scavenging activity. According to these researches methyl-3,5-di-caffeoyquinic acid was assumed to be potentially responsible for the antidiabetic actions of $X$. strumarium L., (Hwang et al., 2016). During the ethnobotanical, phytochemical and toxicological studies of Xanthium strumarium L. carried out by scientists from Bangladesh it was suggested that $X$. strumarium L. was toxic to animal.

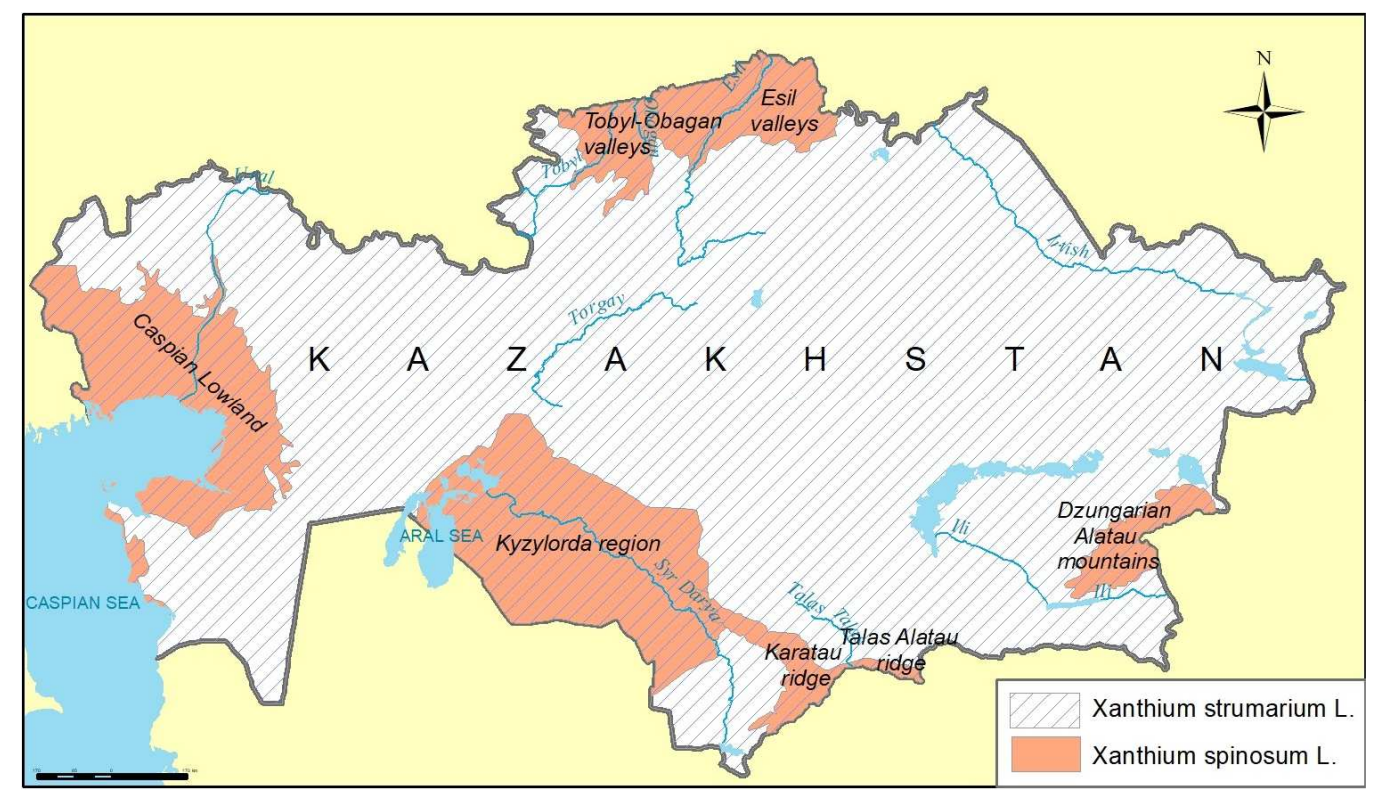

Fig. 1: Regions of the Xanthium L. genus. The species Xanthium strumarium L. is widespread in all regions of Kazakhstan. Xanthium spinosum L. grows in Tobyl-Esil valleys, in regions of the Caspian Sea, in Kyzylorda region, in the Dzungarian Alatau, Karatau, in the Daubaba Mountains and also in the western part of the Talas Alatau 
There were purified four compounds. They were characterized as stigmasterol, 11-hydroxy-11-carboxy-4oxo-1(5),2(Z)-xanthadien-12,8-olide, daucosterol and lasidiol-10-anisate (Islam et al., 2009). Scientists from the UAE reported on the association between herbal extracts and cancer treatment. The effects of Xanthium strumarium L. extract on viability of L929 cell lines were determined. L929 cell lines were divided into 6 groups including the control. The concentrations of Xanthium strumarium L. extract were $10 \mathrm{mg} / \mathrm{mL}, 1 \mathrm{mg} / \mathrm{mL}$, $0.1 \mathrm{mg} / \mathrm{ml}, \quad 0.01 \mathrm{mg} / \mathrm{ml}$ and $0.001 \mathrm{mg} / \mathrm{ml}$. Experiment duration was 48 hours. The viability of L929 cell lines decreased significantly in groups exposed to $10 \mathrm{mg} / \mathrm{ml}$ of extract. So, the results demonstrated that high dose of Xanthium strumarium L. decreases the proliferation of L929 cancer cells (Sahebi-Asghar et al., 2014).

$X$. spinosum L. is an annual plant, it is widespread in the mountains and deserts. In its compound one can find sesquiterpenes, flavonoids, xanthaloids, tannins and essential oils. It possesses the antibacterial and anthelminthic features, calming influence and heals wounds (Grudzinskaya et al., 2014). Romanian scientists have received a drug called "Adenostop" from the squeeze of the cocklebur spiny to use it against bladder disease and urethra disease (Klimakhin et al., 2015). Xanthium L. species also exhibit noticeable antioxidant activity (Sridharamurthy et al., 2011) and chlorogenic acid was of particular abundance in these species (Han et al., 2009). Considering these matters, this study aimed to investigate the correlation between antioxidant activity and chlorogenic acid content of two species of the genus Xanthium L. (Xanthium strumarium L. and Xanthium spinosum L.) harvested from the Kazakhstan spontaneous flora. The quantitative content of chlorogenic acid was estimated by using a newly developed, short and rapid HPLC-DAD method. This study was also intended to explore the antioxidant capacities of the two species by using the ferric reducing antioxidant power (FRAP) method, which based on the reduction of the ferric tripyridyltriazine [Fe(III)-TPTZ] complex to the ferrous tripyridyltriazine [Fe(II)-TPTZ] by a reductant at low pH. Medicinal species of the genus Xanthium L. have curative property and in traditional medicine these species of plants are a subject of great interest as they are used at treatment and prevention of many diseases. Nowadays the species $X$. spinosum L. is insufficiently studied. Therefore, question of studying its anatomic-morphological and phytochemical features are being relevant.

\section{Materials and Methods}

Aim of this work is to study the morphological, anatomical features, chlorogenic acid content and antioxidant activities of two species of the genus Xanthium L.: Xanthium spinosum L., growing in the slopes of Mount
Daubaba in the western part of the Talas Alatau of Tyulkibas region of the South Kazakhstan region and Xanthium strumarium L., growing in the slopes of the Alma-Arasan gorge of the Trans-Ili Alatau, Almaty region.

\section{Morphological and Anatomical Features of Species of the Genus Xanthium L.}

The anatomical structure of vegetative organs of the species $X$. Spinosum L. has not been previously studied. Samples of Xanthium spinosum L., growing in the slopes of Mount Daubaba in the western part of the Talas Alatau of Tyulkibas region of the South Kazakhstan region and Xanthium strumarium L., growing in the slopes of the Alma-Arasan gorge of the Trans-Ili Alatau, Almaty region have been used as objects of study (Fig. 2)

Samples of plants have been determined by the volume VIII of flora of Kazakhstan. Samples of medicinal species Xanthium L. were collected and dried out in August 2016. The collected samples of plants were fixed by the Strasburger-Fleming method (in the ratio 1: 1: $1,70 \%$ alcohol, glycerin and distilled water) and stored in the refrigerator. Structural analysis of the anatomical structure of the medicinal plants of $X$. strumarium L., $X$. spinosum L. have been carried out according to the generally accepted method indicated in the work of (Prozina, 1969).

More than 300 temporary and permanent preparations, fixed in glycerin from the root, stem and leaves have been made. Morphological analysis has been carried out. The digital analysis of the biometric indicators has been measured and photographed on a microscope with a MC100 photomultiplier (magnification $\times 80$ ). Statistical processing of morphometric parameters has been carried out by the method of Lakin (1990). Anatomical features were determined by using the microscope with high resolution and video camera (Austria). Anatomical sections of the external and underground organs of plants have been made using the electronic microtome MZP-01 "Technom". The thickness of the anatomical sections is about $10-15 \mu \mathrm{m}$.

\section{HPLC-DAD Quantitative Analysis of Chlorogenic Acid in Samples}

HPLC-DAD conditions: HPLC chromatographic apparatus consisted of an HPLC Dionex UltiMate 3000 Series system with a DAD-3000 detector, autosampler WPS-3000, TCC-3000 Column Compartments (Thermo Scientific, Germany). The system control, data acquisition and data evaluation were performed by Chromeleon 7 software (Thermo Scientific, Germany). Chromatographic separation was performed on an Hypersil GOLD column $(4.6 \times 150 \mathrm{~mm}$; particle size 5 $\mu \mathrm{m})$. water $+0.1 \%$ phosphoric acid (A) and methanol (B) were used as mobile phase: Gradient: $0-25 \min 15 \% \mathrm{~B}$; 25 - 
$50 \min 15-50 \%$ B; $50-55 \min 50 \%$ B; $55-56 \min 50-15 \%$ B; $56-60 \mathrm{~min} 15 \%$ B. Flow rate was $0.8 \mathrm{ml} / \mathrm{min}$, detection wavelength was $326 \mathrm{~nm}$ and column temperature was $25^{\circ} \mathrm{C}$. The injection volume was $20 \mu \mathrm{L}$.

Preparation of sample solutions: To prepare sample solutions, 1.00 grams of leaves of $X$. strumarium $\mathrm{L}$. (L $X$. strumarium L.), stems of $X$. strumarium L. ( $\mathrm{S}-X$. strumarium L.), leaves of $X$. spinosum L. ( $\mathrm{L}-X$. spinosum L.) and stems of $X$. spinosum L. ( $\mathrm{S}-X$. spinosum L.) were accurately weighted into a $100 \mathrm{~mL}$ round bottom flask separately. Then $50 \mathrm{~mL}$ of $50 \%$ methanol was added to each sample. The sample was heated under a reflux condenser for one hour at a temperature of $85^{\circ} \mathrm{C}$, filtered into a $50 \mathrm{~mL}$ volumetric flask and diluted to scale with $50 \%$ methanol and shaken well. An appropriate amount of subsequent filtrate was then taken and filtered through microporous membrane $(0.45 \mu \mathrm{m})$ to give the sample solution.

Preparation of stock reference solution: To prepare stock reference solution, $2.35 \mathrm{mg}$ of chlorogenic acid reference was accurately weighed, placed in a $25 \mathrm{~mL}$ brown volumetric flask, diluted to the mark with methanol and shaken well to prepare the stock reference solution.

Plotting of standard curve: to generate a standard curve, 1, 2, 4, 6, $10 \mathrm{~mL}$ of the stock solution were accurately drawn; they were placed separately into $10 \mathrm{~mL}$ brown volumetric flasks, diluted to the mark with methanol and shaken well to get the chlorogenic acid solutions. Each $20 \mu \mathrm{L}$ of the reference solutions were taken and determined separately under the "chromatographic conditions" for measurement of peak area values.

Precision test: to test the precision of this method, $20 \mu \mathrm{l}$ of chlorogenic acid of stock solution were accurately drawn and injected five consecutive times under the "chromatographic conditions" for calculation of RSD for chlorogenic acid based on the peak area.

Recovery test: To assess the recovery, five aliquots of samples with known contents were accurately weighed, the appropriate amount of chlorogenic acid reference solution was added separately and then solutions were prepared as it was described above in the "Preparation of sample solutions". Then, the sample solutions were injected and analysed according to the "chromatographic conditions", peak areas were measured and amounts of various constituents were calculated, as well as recoveries.

Repeatability test: Average repeatability variations for determination of chlorogenic acid in samples, expressed as $\%$ RSD for five repeated injections, were determined.

Sample content determination: To determine the content of chlorogenic acid, five aliquots of $1 \mathrm{~g}$ of each sample (L - X. strumarium L., $\mathrm{S}-X$. strumarium L., L $X$. spinosum $\mathrm{L}$. and $\mathrm{S}-X$. spinosum L.) were accurately weighed, prepared into solutions according to the method described above in the "Preparation of sample solutions", then injected and analysed under the "chromatographic conditions". Peak areas were measured and chlorogenic acid contents were calculated. Data were expressed as $\overline{\mathrm{X}} \pm \mathrm{SD}$.

\section{Antioxidant Determination Assay - Ferric Reducing Antioxidant Power (FRAP)}

The total antioxidant capacity of each sample was determined by the Ferric Reducing Antioxidant Potential (FRAP) assay described by Benzie and Strains (1969) with slight modification. The TPTZ solution was prepared by dissolving $0.0308 \mathrm{~g}$ TPTZ in $10 \mathrm{~mL}$ of 40 $\mathrm{mmol} / \mathrm{L} \mathrm{HCl}$. To prepare acetate buffer solution, $25 \mathrm{~g}$ of ammonium acetate were added into $25 \mathrm{~mL}$ distilled water and $38 \mathrm{~mL} 7 \mathrm{~mol} / \mathrm{L}$ hydrochloride, adjusted to $\mathrm{pH}$ 3.6 with $5 \mathrm{~mol} / \mathrm{L}$ ammonia solution or $2 \mathrm{~mol} / \mathrm{L}$ hydrochloric acid, then diluted to $100 \mathrm{~mL}$ solution with redistilled water. Solutions of Xanthium L. samples (S $X$. strumarium L., L - X. strumarium $\mathrm{L}$., $\mathrm{S}-X$. spinosum L., $\mathrm{L}-X$. spinosum $\mathrm{L}$.) were prepared by placing $0.5 \mathrm{~g}$ of dried powdered sample into $100 \mathrm{~mL}$ flask to which 50 $\mathrm{mL}$ of $50 \%$ methanol was added, ultrasonicated for 30 minutes, filtered and transferred into a pre-cleaned flask. A series of standard solutions was prepared from a stock solution of $\mathrm{FeSO}_{4}$ via serial dilution, for final concentrations of $0.1 \mathrm{mmol} /, 0.2 \mathrm{mmol} /, 0.3 \mathrm{mmol} / \mathrm{L}$, $0.4 \mathrm{mmol} /, 0.5 \mathrm{mmol} / \mathrm{L} \mathrm{FeSO}_{4}$. An aliquot of $0.5 \mathrm{~mL}$ solution of each sample or $1.0 \mathrm{~mL}$ of each $\mathrm{FeSO}_{4}$ standard solution was placed into $10 \mathrm{~mL}$ volumetric flask, to which $0.5 \mathrm{~mL}$ TPTZ and $5 \mathrm{~mL}$ acetate buffer solution were added. The solution was then diluted to $10 \mathrm{ml}$ with redistilled water and kept at $37^{\circ} \mathrm{C}$ water bath for 10 minutes for the reaction to proceed. A solution free of $\mathrm{FeSO}_{4}$ but containing same concentrations of TPTZ and acetate buffer was used as a blank. The absorbance of the sample and standard solutions were measured against the blank using UV spectrometer at $593 \mathrm{~nm}$. A standard curve was prepared by plotting the concentration for each standard versus its absorbance. The quantity of antioxidants in samples was then determined using the equation generated by the abovementioned method and expressed as a value of Ferric Reducing Ability of Plasma (FRAP), which means the concentration of antioxidant in the reactive system having a ferric-TPTZ reducing ability equivalent to that of $1 \mathrm{mM} \mathrm{FeSO} 4.7 \mathrm{H}_{2} \mathrm{O}$. Determination of each sample was performed in triplicate.

\section{Statistical Analysis}

Correlation coefficient (R) was used to determine the relationship between two variables. The standard deviations in the morphological and anatomical studies, FRAP assay, as well as in determination of chlorogenic acid content, were calculated from three separate experiments using MS Excel for Windows. 


\section{Results and Discussion}

\section{Botanical Characteristics of the Genus Xanthium L.}

Common cocklebur (Xanthium strumarium L.) is an annual, widespread plant. Its height is $20-100 \mathrm{~cm}$, the stems are straight, pubescent, thinly faceted. On the surface of the stem there are greyish green or brownishgreen spots. Leaves are simple, petiolate, alternately developed. The shape of the leaf blade is roundtriangular or 3-7 wide-ovate, the edges are jagged like a saw, the surface side is green and the lower side is lowered and greyish-green. Tubules flowers are uni-sexual, very small green, collected in oval-spherical basket inflorescences. They develop from the leaf in a spikeshaped way. Inflorescences of the basket are formed from uni-sex flowers. In the upper part of the inflorescence of the basket there are male flowers and in the underside of the basket there are female flowers; five flowers are developed in the male basket and two flowers - in the female basket. Two different baskets of inflorescence are developed in one plant. In July and August, they blossom and bear fruit. Seed germ is green, studded, with length of $12-18 \mathrm{~mm}$, width of 5-10 mm, seeds are elongated (Fig. 2a).

Cocklebur spiny (Xanthium spinosum L.) height is $25-100 \mathrm{~cm}$. The difference of the stalk from the species $X$. strumarium $\mathrm{L}$. is that it is thick, branched, with solid small hairs which are low-directed. It is a creeping plant. Leaves are shortly petiolate, thick, three faced, margins are entire or serrate, middle teeth are larger and sharp, in the surface part of green, there are tightly developing hairs, the underside is also covered with hairs, therefore, they are greyish-green because of furs. At the base of the petiole, shiny yellow thorns are divided into three. Seed germ $\mathrm{mm}$, width is $4-5 \mathrm{~mm}$, elongated, ovate. Outside, there are numerous components of $3 \mathrm{~mm}$ in length, curved hook-shaped thin spines. Its upper part is an acuminate-pointed, $1.5-2 \mathrm{~mm}$ long. It grows at the edges of roads, sandy places and in pastures (Fig. $2 \mathrm{~b}$ )

Cross section of the root of Xanthium strumarium L. is of rounded shape. The epidermis is completely preserved. In the lower part of the epidermis, the exoderm is formed, consisting of several rows of thickened bark. In its inner part there is a layer of the mesoderm, consisting of parenchymal cells having air gaps. Further, there is a layer of the endoderm with several rows of cells. The exoderm, mesoderm and endoderm combine to form a layer of the cortex. The central cylinder consists of xylem tubes, phloem - of filter vessels and followers. The rays formed from xylem tubes are well developed. They are radially elongated. Between the rays, where the xylem ends, there are elements of phloem consisting of a number of colourless cells - pericyclic of primary meristem. Pericyclic is the primary forming tissue. The pericycle forms the lateral roots and parenchymal cells. A number of endoderm cells are located on the outside, which are shown at the top (Fig. 3a).

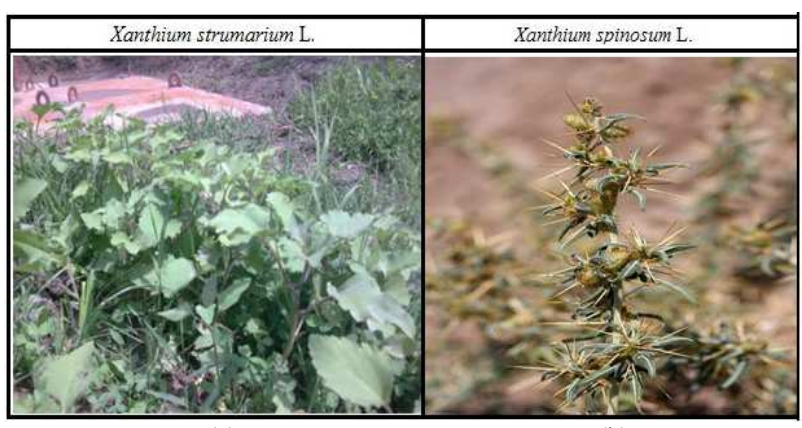

(a)

(b)

Fig. 2: (a) X. strumarium $L$ (b) $X$. spinosum $L$

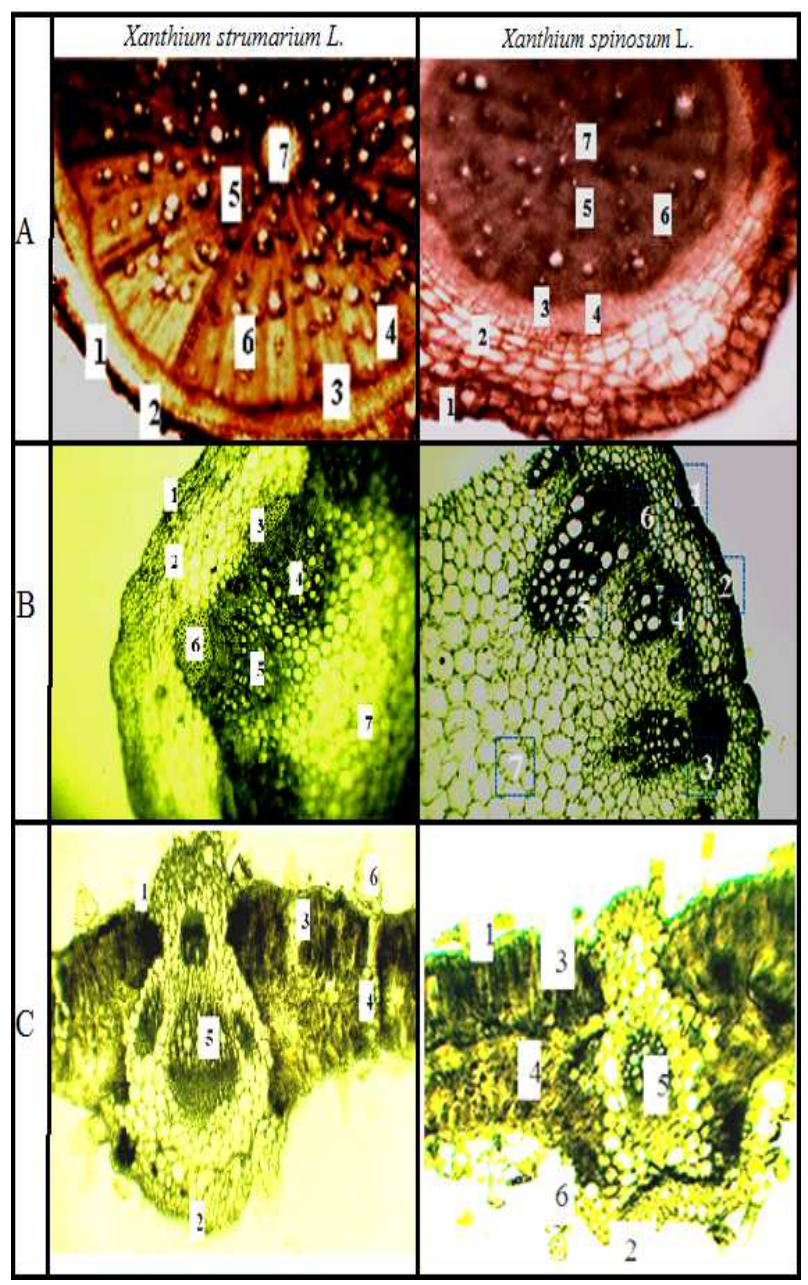

Fig. 3: Anatomical structure of vegetative organs of plants. A - root: 1 - epiderm, 2 - cortex, 3 - endoderm, 4 pericycle, 5 - xylem, 6 - phloem, 7 - pith. B - stem: 1 epidermis, 2 - collenchyma, 3 - boot of sclerenchyma, 4 - conducting beam, 5 - xylem, 6 - phloem, 7 parenchyma cell. C - leaves: 1 - outer epidermis, 2 lower epidermis, 3 - palisade mesophyll, 4 - spongy mesophyll, 5 - conducting beam, 6 - hairs (trichomes)

Cross-section of the root of Xanthium spinosum L. is of rounded shape. The epidermis is completely 
preserved. The root exoderm is well developed. The layer of the mesoderm is thickened. In the species Xanthium spinosum L. xylem tubes are not so many and the number of rays is small. The central cylinder of the species Xanthium spinosum L. is much smaller than in the species $X$. Strumarium L. The bark layer is well developed in the species Xanthium spinosum L. (Fig. 3a).

The surface of the stalk of the plant $X$. strumarium L. is covered with the epidermis. The epidermis is well developed; the cells are tight. The cell membrane of the epidermis is thickened and with cuticles. Outside the endoderm to the epidermis there is a layer consisting of parenchymal cells. The outer cells are rich in chlorophyll grains, where photosynthesis takes place. Then the outer cells from different places turn into angled and flat collenchyma cells. When there are winds they bend down and return to their original form with the help of collenchyma cells. In this way they resist the winds. Also, within the envelope sclerenchymal cells grouped from parenchymal cells are formed. The layer of the membrane ends in the endoderm. The radial shell of the cell and the inner shell of the endoderm cells solidify or suberize weakly. Sometimes some layers of cells without changing are transformed into conductive cells. Inside of the endoderm is a central cylinder. Its surface is covered by a pericycle. If a pericycle is formed from single-row parenchymal cells, then tissue is formed from the newly formed parenchymal cells. In conducting beams, the volume of xylem is well developed compared with phloem (Fig 3b). The shape of closed collateral single conducting beams in the central cylinder is oblong. The conductive beams are exactly arranged in a circle. Number of the conducting beams is $15-20$. The xylem rays are well developed and clearly visible. On the places where the xylem rays begin, the phloem elements are located; they consist of filter tubes and their followers. The pith is formed from parenchymal cells located among the conducting beams. The core is connected to the bark by rays formed from parenchymal cells (Fig. 3b).

In species $X$. spinosum L., from the outside there is the epidermis of the integumentary tissue. From below the epidermis, there is a layer of supporting tissue consisting of collenchyma cells. Inside, there is a well-developed layer of cortex consisting of parenchymal cells. The anatomical structure of the species $X$. spinosum $\mathrm{L}$. is similar to the anatomical structure of $X$. strumarium L. The volume of the phloem of the conducting beams is reduced in comparison with the xylem. The shape of closed collateral single conducting beams in the central cylinder is oblong. Conductive beams are exactly along the circle. In $X$. spinosum L. plant, the xylem rays are well developed. The xylem volume transferring minerals in $X$. spinosum L. plant is more increased than in $X$. strumarium L. The xylem rays are large and widely brightened (Fig. $3 b$ ).
According to the anatomical structure, the leaf of the plant $X$. strumarium L. is dorsoventral. In the transverse section of the leaf, mesophylls are clearly visible. It consists of palisade and spongy tissues. Palisade mesophyll is usually two-row and small-celled. Cells of the spongy mesophyll are widely voluminous.

The lower epidermis of the leaf blade is rotating, between the cells of the epidermis there are stomata, they are easily planted and surrounded by 3-5 epidermal cells.

The upper epidermis is thick, the cell at the bases of the hairs is narrow, the stoma slit with straight walls is rarely found. The epidermis from both platelets is thickened; there are common and glandular hairs, petiolate. Ordinary hairs (trichomes) are not homogeneous, large, solid. The outer cells are rounded, small, the shell is very thick. The lower epidermis is covered with a hair. In the lower epidermis, trichomes are well developed, tips are pointed. The conductive beams are well formed in the central part, clearly expressed and elongated, their number is 4. Outside, there is an axil formed from sclerenchyma cells (Fig 3c).

By the anatomical structure of the leaf, $X$. spinosum L. refers to the dorsoventral type. Leaf mesophyll consists of palisade and spongy tissues. The difference in the anatomical structure of the leaf $X$. spinosum $\mathrm{L}$. compared with that of the $X$. strumarium L. leaf is that the palisade mesophyll consists of three rows of cells. It occupies two thirds of the width of the leaf. The width of the palisade tissue is narrow. In the lower part of the leaf blade, the epidermis is rotating, the cells are thick. The upper and lower sides are covered with hairs. In the central part, the conducting beams are well developed. In the lower epidermis, there are stomata (Fig 3c).

According to the data of anatomical structure of the roots, Xanthium strumarium L. is superior to Xanthium spinosum L. in a number of traits, such as diameters of the central cylinder, xylem and phloem $(\mu \mathrm{m})$ : $1635.25 \pm 3.43,71.06 \pm 1.31,347.13 \pm 4.41$ (for Xanthium strumarium L.) and $803.26 \pm 1.55, \quad 56.69 \pm 1.96$, $137.06 \pm 0.93$ (for Xanthium spinosum L.), respectively. Xanthium strumarium L. is inferior to Xanthium spinosum L. in the thickness of a bark layer $(\mu \mathrm{m})$ : $223.14 \pm 1.89$ and $336.65 \pm 0.56$, respectively (Table 1).

According to the data of anatomical structure of the stems Xanthium strumarium L. is superior to Xanthium spinosum $\mathrm{L}$. in the width of the conductive beam $(\mu \mathrm{m})$ : $870.69 \pm 2.91$ and $548.73 \pm 0.72$, respectively. Xanthium strumarium L. is inferior to Xanthium spinosum L. in the length of the conductive beam $(\mu \mathrm{m}): 1366.66 \pm 1.61$ and $1375.59 \pm 0.82$, respectively. Xanthium strumarium L. is superior to Xanthium spinosum L. in the length of xylem $(\mu \mathrm{m}): \quad 1242.24 \pm 4.31$ and $538.35 \pm 1.10$, respectively. Xanthium strumarium L. is inferior to Xanthium spinosum L. in the width of the xylem $(\mu \mathrm{m})$ : $981.68 \pm 1.98$ and $993.68 \pm 1.19$, respectively (Table 2 ). 
Xanthium strumarium L. is superior to Xanthium spinosum L. in the thickness of the epidermis and collenchyma and the width of cortex parenchyma $(\mu \mathrm{m}): 28.78 \pm 1.56,210.17 \pm 6.24,693.40 \pm 1.03$ (for Xanthium strumarium L.) and 21.46 \pm 1.03 , $162.48 \pm 1.01$ and $357.07 \pm 2.18$ (for Xanthium spinosum L.), respectively (Table 2 ).

According to the data of anatomical structure of the leaves Xanthium strumarium L. is superior to Xanthium spinosum L. in the width of the conductive beam $(\mu \mathrm{m})$ : $226.33 \pm 1.14$ and $164.33 \pm 1.84$, respectively (Table 3 ). Xanthium strumarium L. is inferior to Xanthium spinosum $\mathrm{L}$. in the length of the conductive beam $(\mu \mathrm{m})$ : $349.23 \pm 2.17$ and $385.17 \pm 2.81$, respectively. Xanthium strumarium L. is superior to Xanthium spinosum L. in the thickness of the mesophyll of palisade parenchyma $(\mu \mathrm{m}): \quad 246.33 \pm 1.1$ and $149.33 \pm 1.05$, respectively. Xanthium strumarium L. is superior to Xanthium spinosum L. in the thickness of the mesophyll of spongy parenchyma $(\mu \mathrm{m}): 278.86 \pm 3.38$ and $178.31 \pm 1.5$, respectively. Xanthium strumarium L. is superior to Xanthium spinosum L. in the thickness of the upper epidermis $(\mu \mathrm{m}): \quad 108.54 \pm 2.75$ and $39.61 \pm 0.41$, respectively. And the similar situation one can find for the thickness of the lower epidermis $(\mu \mathrm{m}): 155.76 \pm 2.04$ and $37.53 \pm 0.71$, respectively. Xanthium strumarium L. is superior to Xanthium spinosum L. in the thickness of leaf blade $(\mu \mathrm{m}): \quad 2602.41 \pm 5.75$ and $2048.33 \pm 1.01$, respectively (Table 3 ).

\section{Determination of Chlorogenic Acid Content and Antioxidant Activity of Species of Xanthium L.}

In this study, a simple, precise and repeatable reverse-phase high performance liquid chromatographic method was also developed and validated for the determination of chlorogenic acid in the Xanthium L. species (Fig. 4). Chlorogenic acid detection was carried out with the DAD detector by comparison with the corresponding UV-vis spectra and retention time of its pure standards in the chromatogram (Fig. 5). The maximum absorption wavelength of chlorogenic acid was determined to be $326 \mathrm{~nm}$ within a scanning wavelength range of $190-400 \mathrm{~nm}$. Therefore, $326 \mathrm{~nm}$ was selected as the monitoring wavelength, which was consistent with the reference (Ren et al., 2007).

The standard curve regression equation for chlorogenic acid was as follows: $\mathrm{Y}=774.4 \mathrm{X}$ $3.0257(\mathrm{R}=0.9981$, where $\mathrm{X}$ is the chlorogenic acid concentration in $\mathrm{mg} / \mathrm{ml}, \mathrm{Y}$ is the chromatographic peak area value and $\mathrm{R}$ is the relative regression coefficient, indicating good linearity of the chlorogenic acid within a $9.4 \sim 94.0 \mu \mathrm{g} \bullet \mathrm{mL}^{-1}$ range.

Table 1: Anatomical structure of the root of species of the genus Xanthium L.

\begin{tabular}{|c|c|c|c|c|}
\hline $\begin{array}{l}\text { Plant name and } \\
\text { sampling location }\end{array}$ & $\begin{array}{l}\text { Thickness of a } \\
\text { bark layer }(\mu \mathrm{m})\end{array}$ & $\begin{array}{l}\text { Diameter of the } \\
\text { central cylinder }(\mu \mathrm{m})\end{array}$ & $\begin{array}{l}\text { Diameter of } \\
\text { xylem }(\mu \mathrm{m})\end{array}$ & Diameter of phloem $(\mu \mathrm{m})$ \\
\hline $\begin{array}{l}\text { X. strumarium L. } \\
\text { Alma-Arasan gorge }\end{array}$ & $223.14 \pm 1.89$ & $1635.25 \pm 3.43$ & $71.06 \pm 1.31$ & $347.13 \pm 4.41$ \\
\hline $\begin{array}{l}X \text {. spinosum } \mathrm{L} \text {. } \\
\text { Daubaba Mountain } \\
\text { Note: (with lens } 4 \times\end{array}$ & $336.65 \pm 0.56$ & $803.26 \pm 1.55$ & $56.69 \pm 1.96$ & $137.06 \pm 0.93$ \\
\hline
\end{tabular}

Table 2: Anatomical structure of the stem of species of the genus Xanthium L.

\begin{tabular}{|c|c|c|c|c|c|c|c|}
\hline \multirow[b]{2}{*}{$\begin{array}{l}\text { Plant name and } \\
\text { sampling location }\end{array}$} & \multicolumn{2}{|c|}{$\begin{array}{l}\text { The cross-section of a } \\
\text { conductive beam }(\mu \mathrm{m})\end{array}$} & \multicolumn{2}{|l|}{ Xylem $(\mu \mathrm{m})$} & \multirow[b]{2}{*}{$\begin{array}{l}\text { The thickness of } \\
\text { the epidermis }(\mu \mathrm{m})\end{array}$} & \multirow[b]{2}{*}{$\begin{array}{l}\text { Collen } \\
\text { chyma }(\mu \mathrm{m})\end{array}$} & \multirow[b]{2}{*}{$\begin{array}{l}\text { Cortex parenchyma, } \\
\text { width }(\mu \mathrm{m})\end{array}$} \\
\hline & length & width & length & width & & & \\
\hline $\begin{array}{l}X \text {. strumarium } \mathrm{L} \text {. } \\
\text { Alma-Arasan gorge }\end{array}$ & $1366.66 \pm 1.61$ & $870.69 \pm 2.91$ & $1242.24 \pm 4.31$ & $981.68 \pm 1.98$ & $28.78 \pm 1.56$ & $210.17 \pm 6.24$ & $693.40 \pm 1.03$ \\
\hline $\begin{array}{l}X \text {. spinosum L. } \\
\text { Daubaba Mountain }\end{array}$ & $1375.59 \pm 0.82$ & $548.73 \pm 0.72$ & $538,35 \pm 1.10$ & $993,68 \pm 1.19$ & $21.46 \pm 1.03$ & $162,48 \pm 1.01$ & $357.07 \pm 2.18$ \\
\hline
\end{tabular}

Note: (with lens $4 \times / 0.10$ and multiplication ratio EW $10 \times / 20$ ).

Table 3: Anatomical structure of the leaf of species of the genus Xanthium L.

\begin{tabular}{|c|c|c|c|c|c|c|c|}
\hline \multirow[b]{2}{*}{$\begin{array}{l}\text { Plant name and } \\
\text { sampling location }\end{array}$} & \multicolumn{2}{|c|}{$\begin{array}{l}\text { The cross-section of a } \\
\text { conductive beam }(\mu \mathrm{m})\end{array}$} & \multicolumn{2}{|c|}{$\begin{array}{l}\text { The thickness of } \\
\text { the mesophyll }(\mu \mathrm{m})\end{array}$} & \multicolumn{2}{|c|}{$\begin{array}{l}\text { The thickness of the } \\
\text { epidermis }(\mu \mathrm{m})\end{array}$} & \multirow[b]{2}{*}{$\begin{array}{l}\text { The thickness of } \\
\text { leaf blade }(\mu \mathrm{m})\end{array}$} \\
\hline & length & width & $\begin{array}{l}\text { palisade } \\
\text { parenchyma }\end{array}$ & $\begin{array}{l}\text { spongy } \\
\text { parenchyma }\end{array}$ & upper & lower & \\
\hline X. strumarium L. & 349.23 & 226.33 & 246.33 & 278.86 & 108.54 & 155.76 & 2602.41 \\
\hline Alma-Arasan gorge & \pm 2.17 & \pm 1.14 & \pm 1.1 & \pm 3.38 & \pm 2.75 & \pm 2.04 & \pm 5.75 \\
\hline X. spinosum L. & 385.17 & 164.33 & 149.33 & 178.31 & 39.61 & 37.53 & 2048.33 \\
\hline Daubaba Mountain & \pm 2.81 & \pm 1.84 & \pm 1.05 & \pm 1.50 & \pm 0.41 & \pm 0.71 & \pm 1.01 \\
\hline
\end{tabular}

Note: (with lens $4 \times / 0.10$ and multiplication ratio EW $10 \times / 20$ ) 

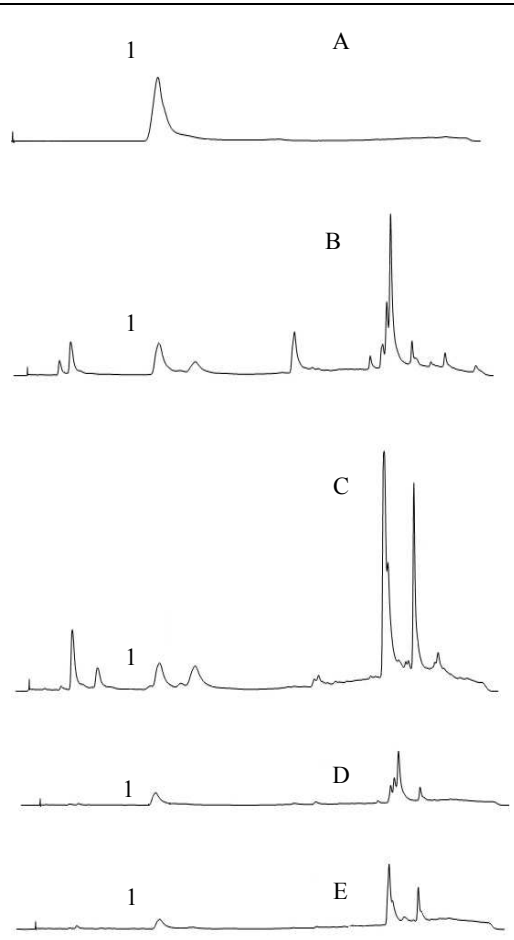

Fig. 4: HPLC chromatograms of chlorogenic acid solution and sample solutions. A. standard solution B. Leaves of $X$. strumarium L., C. Leaves of $X$. spinosum L., D. stem of $X$. strumarium L., E. stem of $X$. spinosum L., 1 . chlorogenic acid

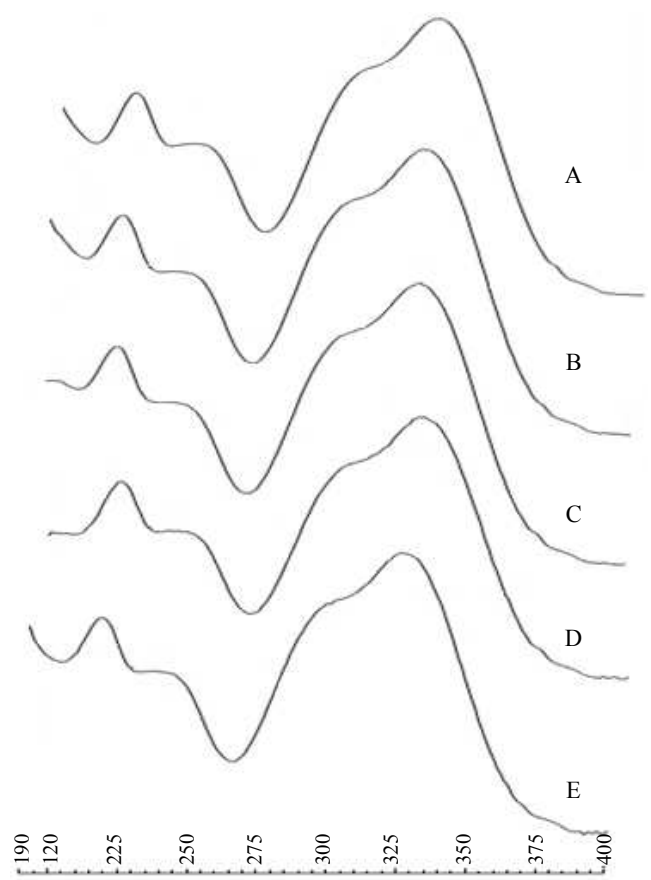

Fig. 5: UV-vis spectra for chromatographic peak of chlorogenic acid in different samples (including reference). A. standard solution B. Leaves of $X$. strumarium L., C. Leaves of $X$. spinosum L., D. stem of $X$. strumarium L., E. stem of $X$. spinosum L.
RSD of precision test for chlorogenic acid was calculated to be $0.83 \%$, indicating qualified precision of the test instrument. Average recovery of chlorogenic acid in extracts from $\mathrm{L}-X$. strumarium $\mathrm{L}$., $\mathrm{S}-X$. strumarium $\mathrm{L}$., $\mathrm{L}-X$. spinosum $\mathrm{L}$. and $\mathrm{S}-X$. spinosum $\mathrm{L}$. were determined to be $91.14,97.83,99.32$ and $98.88 \%$, respectively, indicating that the method was accurate and reliable for quantitative determination of chlorogenic acid in $X$. strumarium L. and $X$. spinosum $\mathrm{L}$. RSD value of repeatability test was determined to be less than $4.55 \%$, indicating a good repeatability of this method.

The above mentioned validation studies show that the method is suitable for the determination of chlorogenic acid in extracts from Xanthium L. species. Using this method, chlorogenic acid contents in $\mathrm{L}-X$. strumarium L., $\mathrm{S}-X$. strumarium $\mathrm{L}$., $\mathrm{L}-X$. spinosum $\mathrm{L}$. and $\mathrm{S}-X$. spinosum $\mathrm{L}$. were determined to be $1.306,0.698,1.606$ and $0.613 \mathrm{mg} / \mathrm{g}$, respectively.

Chlorogenic acid is quantitatively determined mainly by HPLC (Ren et al., 2007), TLC (HPTLC) (Urakova et al., 2008), capillary zone electrophoresis (Yan et al., 2004) and spectrophotometry (Dao and Friedman, 1992) at present. In view of multiple interference constituents in $X$. strumarium L. and $X$. spinosum L., HPLC was selected for its quantification. Existing studies have shown that plants from the genus Xanthium L. contains a variety of chemical constituents, mainly volatile oil substances, sesquiterpene lactones, water-soluble glycosides, fatty acids, phenolic compounds, organic acids, etc. Phytochemicals have different dissolution properties in different solvents. In general, water is suitable for extracting hydrophilic constituents such as proteins, saccharides, tannins and glycosides. Hydrophilic constituents are mostly soluble in ethanol or methanol as well. As far as chlorogenic acid is concerned, methanol or ethanol is a good choice. The preliminary experiment found that $50 \%$ methanol was the suitable extraction solvent for $X$. strumarium L. and $X$. spinosum $\mathrm{L}$.

According to the result of antioxidant determination assay, Xanthium L. samples showed a certain degree of antioxidant activity, mainly those with high levels of chlorogenic acid contents. The FRAP value of the samples in decreasing order was $\mathrm{L}-X$. spinosum $\mathrm{L}$. (0.1073), L $X$. strumarium L. (0.1061), $S-X$. strumarium L. (0.1027), $S-X$. spinosum L. (0.0958). According to the result of a correlation analysis, the total antioxidant activities of Xanthium L. samples investigated correlated well with chlorogenic acid $\left(\mathrm{R}^{2}=0.79\right)$, indicating that chlorogenic acid could be important contributors of antioxidant capacities of Xanthium L. samples.

\section{Conclusion}

In the course of the research, the anatomical and morphological features of medicinal plants Xanthium L. grown in the conditions of Almaty and South Kazakhstan regions have been studied. 
For the first time the anatomical features of vegetative organs and the morphological features of the studied species have been described.

For the first time in Kazakhstan the morphological and anatomical structure of the vegetative organs of medicinal plants of the species Xanthium spinosum L. have been analysed.

The study of anatomical and morphological features of medicinal plant species Xanthium L. complements the description of their intraspecific features. Description of anatomy and diagnostic traits of vegetative organs of medicinal plants increases the quality of selection for their use in raw pharmacology.

As a result of studies of the morphological features of medicinal plant species Xanthium L., the description of their morphological features is given. The main stem of the plant $X$. strumarium L. grows straight, the stems are branched, straight and leaves are petiolate. The main root is well developed, in comparison with the lateral root, the main root is long and thick. The height of Xanthium spinosum L. is $25-100 \mathrm{~cm}$. Stems differ from the species $X$. strumarium L. - they are dense, branched and small, hard hairs are directed downward.

The study of the anatomical structure of medicinal plants Xanthium L. showed that the cross sections of the root are round. The epidermis is completely preserved. Outside, the stems of the species Xanthium L. are covered with the epidermis, the epidermis being well developed. $X$. spinosum L. plants have a well-developed ray xylem. The amount of xylem that conducts solutions of mineral salts in $X$. spinosum $\mathrm{L}$. plants is greater than in $X$. strumarium L. The leaves of plants Xanthium L. are anatomically dorsoventral. On the cross section of the leaf, the upper columnar layer and the lower loose layer of the mesophyll are clearly visible.

Determination of chlorogenic acid in Xanthium L. species has been successfully achieved by the use of a validated HPLC-DAD method. The method is accurate, precise and reliable for the quality control evaluation of herbal preparations containing Xanthium L. species.

The result of FRAP test has shown that Xanthium L. samples possess a certain degree of antioxidant activity, mainly those with high levels of chlorogenic acid contents, indicating that chlorogenic acid could be important contributors of antioxidant capacities of Xanthium L. samples.

\section{Acknowledgement}

This study was supported by National Natural Science Foundation of China (Grant No. 81360499) and Training Project for Scientific and Technological Talents of Xinjiang Uighur Autonomous Region (Grant No. QN2016YX0759).

\section{Author's Contributions}

All authors participated in all experiments, coordinated the data-analysis and contributed to the writing of the manuscript.

\section{Ethics}

All authors declare no conflict of interest.

\section{References}

Benzie, I.F.F. and J.J. Strain, 1969. The ferric reducing ability of plazma frap as a measure of "antioxidant power": The frap assay. Anal. Biochem., 239: 70-76. DOI: 10.1006/abio.1996.0292

Bhogaonkar, P.Y. and S.A. Ahmad, 2012. Pharmacognostic studies on Xanthium strumarium L. - a folk Unani medicinal herb. Biosci. Discovery, 3: 101-106

Dao, L. and M. Friedman, 1992. Chlorogenic acid content of fresh and processed potatoes determined by ultraviolet spectrophotometry. J. Agric. Food Chem., 40: 2152-2156. DOI: 10.1021/jf00023a022

Dong, K.K., K.S. Chang, W.B. Dong, S.K. Yeon and Y. Min-Suk et al., 2002. Identification and biological characteristics of an antifungal compound extracted from Cocklebur (Xanthium strumarium) against Phytophthora drechsleri. Plant Pathol. J., 18: 288-292. DOI: 10.5423/PPJ.2002.18.5.288

Flora of Kazakhstan, 1961. Flora of Kazakhstan. 8th Edn., The Academy of Sciences of the Kazakh SSR, Almaty.

Georgievsky, V.P., N.F. Komisarenko and S.E. Dmitruk, 1990. Biologically active substances of medicinal plants. Novosibirsk: Nauka.

Grudzinskaya, L.M., N.G. Gemedzhieva and Z.Z. Karzhaubekova, 2014. Annotated list of medicinal plants of Kazakhstan, Almaty.

Han, T., H.L. Li, Q.Y. Zhang, P. Han and H.C. Zheng et al., 2007. Bioactivity-guided fractionation for antiinflammatory and analgesic properties and constituents of Xanthium strumarium L. Phytomedicine, 14: 825-829. DOI: 10.1016/j.phymed.2007.01.010

Han, T., Q.Y. Zhang, Z. Hong, J. Wen and Y. Wang et al., 2009. Authentication and quantitative analysis on the chemical profile of Xanthium fruit (cang-er-zi) by high-performance liquid chromatography-diodearray detection tandem mass spectrometry method. Anal. Chim. Acta, 634: 272-278.

DOI: $10.1016 /$ j.aca.2008.12.027

Hwang, S.H., Z. Wang and H.N. Yoon, 2016. Xanthium strumarium as an Inhibitor of $\alpha$-glucosidase, protein tyrosine phosphatase $1 \beta$, Protein Glycation and ABTS+ for Diabetic and Its Complication. Molecules, 21: 12-41.

DOI: 10.3390/molecules21091241 
Islam, M.R., M.Z. Uddin and M.S. Rahman, E. Tutul and M.Z. Rahman et al., 2009. Ethnobotanical, phytochemical and toxicological studies of Xanthium strumarium L. Bangladesh Med. Res. Council Bull., 35: 84-90. PMID: 20922910

Kamboj, A., P. Atril and A.K. Saluja, 2014. Phytochemical Screening, In-vitro Evaluation of Antioxidant and Free Radical Scavenging Activity of Leaves, Stems and Roots of Xanthium strumarium L., (Compositae). Br. J. Pharma. Res., 4: 1-22. DOI: $10.9734 / \mathrm{BJPR} / 2014 / 3667$

Kim, H.S., T.S. Lee, S.W. Yeo, L.S. Seong and T.S. Yu, 2003. Isolation and characterization of antitumor agents from Xanthium strumarium L. Korean Society Biotechnol. Bioeng. J., 18: 324-328.

Klimakhin, G.I., V.S. Fonin, V.Y. Maslyakov, N.B. Fadeev and V.V. Semikin et al., 2015. Biochemical features of common cocklebur (Xanthium strumarium L.). Pharma. Chem. J., 49: 547-550. DOI: $10.1007 / \mathrm{s} 11094-015-1324-7$

Lakin, G.F., 1990. Biometrics. 1st Edn., High School, Moscow, pp: 352.

Prozina, M.N., 1969. Botanical Microelectronics. 1st Edn., Moscow, pp: 208.

Rakhimov, K.D., Z.A. Satybaldiyeva and G.S. Sukhoreva, 1999. A guide to working with medicinal plants.

Ramírez-Erosa, Y.H., R.A. Hickie, R.G. Sutherland and B. Barl, 2007. Xanthatin and xanthinosin from the burs of Xanthium strumarium L. as potential anticancer agents. Canadian J. Physiol. Pharmacol., 85: 1160-1172. DOI: 10.1139/Y07-104

Ren, Z., X. Gu, S. Hou, S. Hou and X. Zhao et al, 2007. HPLC determination of chlorogenic acid in suke ganmao tablets. Chinese J. Pharma. Anal., 27: $752-753$.
Sahebi-Asghar, R., M. Kassaee, R. Ahmadi and P. Tavakoli, 2014. The effects of hydroalcoholic extract of Xanthium Strumarium on L929 tumor cell line. Proceedings of the International Conference on Earth, Environment and Life Sciences, Dec. 23-24, Dubai (UAE), pp: 21-22.

DOI: $10.15242 / \mathrm{IICBE} . \mathrm{C} 1214110$

Salekh, K.AG., 2010. Pharmacognostic research of plants of the genus Xanthium L. PhD Thesis, Kursk.

Sridharamurthy, N.B., R. Yogananda and U. Srinivas, 2011. In-vitro antioxidant and antilipidemic activities of Xanthium strumarium L. Curr. Trends Biotechnol. Pharm., 5: 1362-1371.

Suresh, J., R. Rajan and Nagamani, 2014. Anti-diabetic activity of aerial parts of Xanthium strumarium Linn. World J. Pharm. Pharma. Sci., 3: 2185-2200.

Urakova, I.N., O.N. Pozharitskaya, A.N. Shikov, V.M. Kosman and V.G. Makarov et al., 2008. Comparison of high performance TLC and HPLC for separation and quantification of chlorogenic acid in green coffee bean extracts. J. Separat. Sci., 31: 237-241. DOI: $10.1002 /$ jssc. 200700472

Yan, J., M. Wang and J. Lu, 2004. Determination of rutin, quercetin and chlorogenic acid in mulberry leaves by capillary zone electrophoresis. Anal. Lett., 37: 3287-3297. DOI: 10.1081/AL-200040356

Yin, M.H., D.G. Kanga, D.H. Cho, T.O. Kwon and H.S. Lee, 2005. Screening of vaso relaxant activity of some medicinal plants used in oriental medicines. J. Ethnopharmacol., 99: 113-117.

DOI: $10.1016 /$ j.jep.2005.02.013 